\title{
Offshore heavy mineral placer formation: Characterisation, provenance and sediment dynamics
}

\author{
S. BURKE ${ }^{1,3^{*}}$, A. J. WHEELER ${ }^{1,3}$, \\ D. $\mathrm{CHEW}^{2,3}$
}

${ }^{1}$ School of Biological, Earth and Environmental Sciences, University College Cork, Ireland

${ }^{2}$ School of Natural Sciences, Trinity College Dublin, Ireland ${ }^{3}$ Irish Centre for Research in Applied Geosciences (iCRAG)

*siobhan.burke@icrag-centre.org

Heavy minerals sands are comprised of mineral grains with a density $>2.9 \mathrm{~g} / \mathrm{cm}^{3}$, and their occurrence is typically linked to the proximity of igneous and / or metamorphic source terrane(s). In addition to the presence of suitable crystalline basement source(s), their distribution and accumulation is controlled by density-driven sorting during transport and deposition. In NW Ireland, offshore heavy mineral sand deposits are present as placer deposits. A multiproxy approach is being employed to quantify, characterise and map the sands using a combination of Raman grain identification and detrital U-Pb geochronology and trace element analyses of accessory minerals (zircon, rutile, apatite and titanite). Understanding source terranes and sediment transport pathways is imperative for identifying heavy mineral concentrations elsewhere.

Thirty-six offshore samples from three separate bays were analysed using a semi-automated Raman technique. Initial results of the heavy mineral assemblages show that most inshore samples direct reflect the proximal crystalline basement sources onshore. In contrast, samples further offshore in bays that experience strong Atlantic currents (e.g. Clew Bay) show mixing between two separate sources.

Samples from south Clew Bay are consistent with an ultramafic, ophiolitic source (presence of olivine, pyroxene, amphibole and serpentine group minerals), while north Clew Bay samples are derived from Dalradian Supergroup metasedimentary rocks (typical assemblages of epidote, garnet, zircon, rutile and staurolite). Individual samples display a low ZTR index, indicating that the sediment is immature and has not undergone significant recycling. Trends in sediment grain size and composition can be used as vectors for concentration and used to further identify spatial and temporal variations in sediment sources. 